\title{
Effect of Different Organic Nutrient Sources on Soil Properties in Onion (Allium cepa L.)
}

\author{
Ravina Kumari*, Kuldeep Singh Thakur and Noel Lalhruaitluangi \\ Department of Vegetable Science, Dr YS Parmar University of Horticulture and Forestry, \\ Nauni, Solan (HP)-173230, India \\ *Corresponding author
}

\begin{tabular}{|l|}
\hline Ke y w or d s \\
Vemcompost, \\
Jeevamrut, \\
Available NPK and \\
NPK Uptake \\
\hline Article Info \\
\hline $\begin{array}{l}\text { Accepted: } \\
15 \text { March } 2019 \\
\text { Available Online: } \\
\text { 10 April } 2019\end{array}$ \\
\hline
\end{tabular}

A B S T R A C T

The present investigation entitled, "Studies on Effect of Organic Nutrient Sources on nutrient uptake and different soil properties in onion (Allium cepa L.)" was carried out at Organic Block of Experimental Farm, Department of Vegetable Science, Dr YS Parmar University of Horticulture and Forestry, Nauni, Solan, (HP) in the Rabi season 2016-2017 with the aim to understand the effect of organic nutrient sources on nutrient uptake and different soil properties in onion cv. 'Palam Lohit'. The experiment was laid in Randomized Complete Block Design (Factorial) with three replications comprising of ten treatments. Organic manures with five levels [ $\mathrm{M}_{0}$ (No Manure), $\mathrm{M}_{1}\left(\mathrm{FYM} @ 25 \mathrm{t} \mathrm{ha}^{-1}\right), \mathrm{M}_{2}$ (Vermicompost @ $\left.8 \mathrm{t} \mathrm{ha}^{-1}\right), \mathrm{M}_{3}$ (FYM $50 \%$ + VC $\left.\left.50 \%\right), \mathrm{M}_{4}(\mathrm{FYM} 75 \%+\mathrm{VC} 25 \%)\right]$ was the first factor and application of liquid manure with two level $\left[\mathrm{L}_{0}\right.$ (No liquid manure), $\mathrm{L}_{1}$ (Liquid manure i.e. Jeevamrut)] was the second factor. The results revealed that treatment $\mathrm{T}_{8}$ [Vermicompost @ $8 \mathrm{t} \mathrm{ha}^{-1}+$ Jeevamrut (Drenching, 5\%)] recorded maximum $\mathrm{N}, \mathrm{P}, \mathrm{K}$ content in soil $\left(336.16,62.24\right.$ and $\left.362.64 \mathrm{~kg} \mathrm{ha}^{-1}\right)$ and $\mathrm{N}, \mathrm{P}, \mathrm{K}$ uptake by plant $\left(151.93,28.86\right.$ and $\left.57.19 \mathrm{~kg} \mathrm{ha}^{-1}\right)$. The same treatment also resulted in highest net return (Rs. 7, 08,895.37) and B:C ratio (4.74). Hence, it can be concluded that application of [Vermicompost@8 $\mathrm{t} \mathrm{ha}^{-1}+$ Jeevamrut (Drenching, 5\%)] optimized the nutrient requirement of the onion crop for better yield with maximum return and advantage of environment protection and soil health.

\section{Introduction}

Onion (Allium cepa L.) is one of the important commercial bulbous vegetable crops grown worldwide and belongs to family amaryllidaceae. According to Vavilov (1951), the primary center of origin lies in Central Asia. The Near East and Mediterranean is the secondary center of origin. It is also a good source of antioxidant, flavonoid and quercetin which is found to have anti-carcinogenic, anti-inflammatory and anti-diabetic functions. Onion is the largest bulbous vegetable produced and consumed not only in India but also in the world. Although it is classified as a vegetable, it has special qualities, which add to the taste and flavour to food and hence it is mainly used in Indian cuisine and culinary 
preparations. In addition to its use in cuisine, it is also relished in raw form with meals. It is liked for its flavour and pungency which is due to the presence of a volatile oil 'allyl propyl disulphide'- organic compound rich in sulphur. Onion is consumed by all classes of people - poor and rich, hence assumes a place of essential item. Onion possesses very good nutritive and medicinal values. It is used in diverse form of food like salad, soups, spices, condiments and it has properties to prevent heart diseases and other ailments.

The heavy use of chemicals has led to degeneration of soil, water and ultimately the quality of food materials. So, at this moment a keen awareness has started in all parts of India for adoption of organic cultivation to cure the ills of modern organic agriculture.

Organic nutrient sources, such as FYM and vermicompost along with liquid organic nutrient source i.e. jeevamrut improves soil physical properties (structure and aggregation) and soil chemical properties (decrease soil $\mathrm{pH}$, increase cation exchange capacity and enhance availability of most nutrients) that are important for plant growth.

The organic manure seems to act directly for increasing crop yield by accelerating the respiratory process through cell permeability or by hormones through growth action. It supplies nitrogen, phosphorus and sulphur in the available form to the plants through biological decomposition.

\section{Materials and Methods}

The present study was carried out at Experimental Farm of the Department of Vegetable Science, Dr YS Parmar University of Horticulture and Forestry, Nauni, Solan (HP) during Rabi season of 2016-2017. The experiment was laid in Randomized Complete Block Design (Factorial) with three replications comprising of ten treatments. Organic manures with five levels $\left[\mathrm{M}_{0}\right.$ (No Manure), $\mathrm{M}_{1} \quad\left(\mathrm{FYM} \quad @ \quad 25 \mathrm{t}^{\mathrm{h}} \mathrm{ha}^{-1}\right), \mathrm{M}_{2}$ (Vermicompost @ $8 \mathrm{tha}^{-1}$ ), $\mathrm{M}_{3}$ (FYM $50 \%+$ VC $50 \%), \mathrm{M}_{4}$ (FYM $75 \%+$ VC $25 \%$ )] was the first factor and application of liquid manure with two level $\left[\mathrm{L}_{0}\right.$ (No liquid manure), $\mathrm{L}_{1}$ (Liquid manure i.e. Jeevamrut)] was the second factor. The organic manures (vermicompost and well rotten farm yard manure) were applied at the time of land preparation as per the treatments in the respective plots. For conducting the experiment jeevamrut was prepared at the Experimental Farm of Dr YS Parmar University of Horticulture and Forestry, Nauni, Solan, (HP). All materials required for its preparation were available at the farm itself except jaggery and pulse floor. Jeevamrut 5 per cent (5 1 per 1001 of water) was applied as soil drench at the time of transplanting, 15, 30, 60 days after transplanting of the seedlings.

\section{Soil analysis}

Soil samples were collected from a depth of $0-15 \mathrm{~cm}$ before layout of the experiment (Results shown in Table 1) and after the harvest of the crop. The soil samples were air dried, grinded with wooden pestle and mortar and passed through $2 \mathrm{~mm}$ sieve and stored in cloth bags for physico-chemical analysis of soil pH, EC, OC, N, P and K content. Detail of methods followed for the estimation of $\mathrm{pH}$, EC, OC and available N, P and K contents by adopting standard methods are:

$\mathrm{pH}$ and EC of soil samples were recorded through digital $\mathrm{pH}$ meter and electrical conductivity meter respectively and organic carbon (OC) content of the samples was determined by chromic and titration method suggested by Walkley and Black (1934). Available $\mathrm{N}$ was determined by alkaline potassium permanganate method (Subbiah 
and Asija, 1956) and available $P$ was determined by stannous chloride reduced molybdate method in HCL system (Olsen et al., 1954). Available $\mathrm{K}$ was extracted by normal neutral ammonium acetate method (Mervin and Peech, 1951)

\section{Plant analysis}

The plant samples for analysis of nutrient uptake were collected at the time of harvest. All the samples were washed in series, first with tap water and then with $0.1 \mathrm{~N}$ HCL followed by distilled water. Samples were kept under proper shady condition for proper air drying. After air drying the samples were cut into pieces and the samples were oven dried at $65^{\circ} \mathrm{C}$. The dried samples were then grinded in an electrical grinder and stored in butter paper bags for chemical analysis of nitrogen, phosphorus and potash uptake by the plants.

For estimation of $\mathrm{N}, 1.0 \mathrm{~g}$ of plant material was digested in concentrated $\mathrm{H}_{2} \mathrm{SO}_{4}$ in the presence of a digestion mixture. After digestion, the $\mathrm{N}$ was determined by microKjeldahl method.

For the estimation of $\mathrm{P}$ and $\mathrm{K}, 1.0 \mathrm{~g}$ of the plant sample was digested in 4:1 nitric acid and perchloric acid $\left(\mathrm{HNO}_{3}: \mathrm{HClO}_{4}\right)$ mixture. In order to have complete transfer of the digestion, three washing of the digestion flask were given with distilled water and volume was made to $100 \mathrm{ml}$. Potassium in the extract was determined by flame-photometer and $\mathrm{P}$ was determined by Vanado - molybdate yellow color method (Jackson, 1973)

\section{Economics of treatments}

The economics of treatments is the most important consideration of making any recommendation to the farmer for its adoption. The prices of inputs that were prevailing at the time of their use were considered for working out the cost of cultivation. Gross return was worked out on the basis of market price of the produce at the time when the produce was ready for sale.

Net return (Rs. ha ${ }^{-1}$ ) was calculated by deducting cost of cultivation (Rs. ha ${ }^{-1}$ ) from the gross income. Benefit cost ratio was worked out as follow,

B: $\mathrm{C}$ ratio $=\frac{\text { Net returns }\left(\text { Rs. ha }{ }^{-1}\right)}{\begin{array}{l}\text { Cost of cultivation (Rs. } \\ \left.\text { ha }^{-1}\right)\end{array}}$

\section{Statistical analysis}

All the data pertaining to growth, yield and quality characters of onion were subjected to statistical analysis to find out the significance of the results obtained. The statistical analysis was carried out for each observed character under study, using MS-Excel and OPSTAT packages. The mean value of data subjected to analysis of variance as described by Panse and Sukhatme (2000) for using Randomized Complete Block Design (Factorial).

\section{Results and Discussion}

\section{Soil pH}

It can be investigated from the data presented in Table 2, that the application of different organic manures had non-significant influence on soil $\mathrm{pH}$, however $\mathrm{pH}$ value ranged from $7.21-7.28$ Treatment $\mathrm{L}_{1}$ (application of liquid manure) showed significantly less $\mathrm{pH}$ value (7.22) over the treatment $\mathrm{L}_{0}$ (No liquid manure) which showed the $\mathrm{pH}$ value of (7.28).

Combination of organic manures and liquid manure also showed non-significant differences in soil $\mathrm{pH}$, however $\mathrm{pH}$ value ranged from $7.19-7.30$. 
Rai et al., (2014) also recorded decrease in soil $\mathrm{pH}$ with the addition of organic manures. The possible reason for the decrease in soil $\mathrm{pH}$ might be due to release of organic acids during the process of decomposition. Liquid manure accelerated the decomposition of organic manures hence decrease in $\mathrm{pH}$ was noticed in the treatment which included application of liquid manures along with organic manures.

\section{Soil EC $\left(\mathrm{dSm}^{-1}\right)$}

Data pertaining to soil EC as presented in the Table 2 revealed that application of organic manures showed significant effect on the soil EC. Maximum soil EC $\left(0.36 \mathrm{dSm}^{-1}\right)$ was observed in control treatment and minimum soil EC $\left(0.26 \mathrm{dSm}^{-1}\right)$ was observed with the application of vermicompost $\left(\mathbf{M}_{2}\right)$, which was at par with $\mathrm{M}_{1}, \mathrm{M}_{3}$ and $\mathrm{M}_{4}$.

Treatment $\mathrm{L}_{1}$ (application of liquid manure) registered significantly lower EC value (0.26 $\mathrm{dSm}^{-1}$ ) than $\mathrm{L}_{0}$ (No liquid manure) i.e.0.31 $\mathrm{dSm}^{-1}$.

Combination of organic manures and liquid manure showed significant effect for soil EC. Significantly lower soil EC $\left(0.22 \mathrm{dSm}^{-1}\right)$ was recorded in treatment $\mathrm{M}_{2} \mathrm{~L}_{1}$ [Vermicompost @ $8 \mathrm{t} \mathrm{ha}^{-1}+$ Jeevamrut (Drenching, 5\%)] while maximum EC value $\left(0.38 \mathrm{dSm}^{-1}\right)$ was recorded by the treatment $\mathrm{M}_{0} \mathrm{~L}_{0}$ (No manure + No liquid manure). Decrease in EC may be attributed due to leaching of salts and increased soil permeability. These results are in consonance with the finding of Rai et al., (2014) who also noticed decrease in soil EC with addition of organic manures.

\section{Soil organic carbon (\%)}

Different treatments of organic manures, liquid manure and their combination significantly influenced the soil organic carbon (Table 2). Maximum organic carbon content $(1.29 \%)$ was recorded by the application of vermicompost which is at par with $\mathrm{M}_{1}(1.26 \%)$ while minimum soil organic carbon content $(1.13 \%)$ was recorded in $\mathrm{M}_{0}$.

Significantly higher organic carbon content i.e. 1.23 per cent was recorded in treatment $\mathrm{L}_{1}$ over the treatment $\mathrm{L}_{0}(1.18 \%)$.

From the results of interaction effect it was noticed that application of vermicompost @ 8 $\mathrm{t} \mathrm{ha} \mathrm{a}^{-1}+$ jeevamrut (Drenching, 5\%) recorded maximum organic carbon content $(1.38 \%)$ while minimum organic carbon content $(1.08$ $\%)$ was recorded in control treatment $\left(\mathrm{M}_{0} \mathrm{~L}_{0}\right)$.

The increase in organic carbon content with application of vermicompost and liquid manure may be attributed to the higher direct incorporation of organic materials and better root growth. The subsequent decomposition of these materials might have resulted in enhanced organic carbon content of soil. These results also corroborate with the findings of Rai et al., (2014) and Singh et al., (2014).

\section{Available NPK content in soil $\left(\mathrm{kg} \mathrm{ha}^{-1}\right)$}

Data pertaining to available $\mathrm{N} P$ and $\mathrm{K}$ content in the soil after completion of experiment has been summarized in Table 2 .

From the results it was inferred that the different organic manure treatments and their combination with liquid manure had significant effect on available nitrogen content in soil after harvest. Significantly higher amount of available nitrogen in soil $\left(324.30 \mathrm{~kg} \mathrm{ha}^{-1}\right)$ was observed in treatment $\mathrm{M}_{2}$ (vermicompost) over control, which was followed by treatment $\mathrm{M}_{1}$ while minimum amount $\left(251.65 \mathrm{~kg} \mathrm{ha}^{-1}\right)$ was observed in treatment $\mathbf{M}_{0}$. Drenching of soil with liquid manure also had significant effect on 
available nitrogen content. Liquid manure application registered significantly more available nitrogen $\left(312.24 \mathrm{~kg} \mathrm{ha}^{-1}\right)$ than no liquid manure application which registered available nitrogen content of $294.81 \mathrm{~kg} \mathrm{ha}^{-1}$. Regarding the interaction effect, the treatment $\mathrm{M}_{2} \mathrm{~L}_{1}$ registered maximum (336.16 $\mathrm{kg} \mathrm{ha}^{-1}$ ) available nitrogen content followed $\mathrm{M}_{1} \mathrm{~L}_{1}$ whereas minimum nitrogen content (246.67 $\mathrm{kg} \mathrm{ha}{ }^{-1}$ ) was registered in $\mathrm{M}_{0} \mathrm{~L}_{0}$. This is attributed to the favourable soil conditions under these treatments and application of jeevamrut might have helped in mineralization of soil $\mathrm{N}$ leading to build up of higher available nitrogen. Increase in available nitrogen with vermicompost or FYM application might be due to mineralization of $\mathrm{N}$ from organic manures in soil and greater multiplication of soil microbes, which could convert organically bound $\mathrm{N}$ to inorganic form. Similar finding were reported by Rai et al., (2014) and Singh et al., (2014).

The available phosphorus content of soil was influenced significantly by different organic manure treatments. Maximum amount of available phosphorus in soil (51.85 kg ha $\left.{ }^{-1}\right)$ was observed in treatment $\mathrm{M}_{2}$ followed by application of FYM $\left(\mathrm{M}_{1}\right)$ and minimum amount (32.60 kg ha-1) was observed in treatment $\mathbf{M}_{0}$. Liquid manure application registered higher available phosphorus (52.70 $\mathrm{kg} \mathrm{ha}{ }^{-1}$ ) than no liquid manure application which registered available phosphorus content of $37.12 \mathrm{~kg} \mathrm{ha}^{-1}$. Regarding the interaction effect the treatment $\mathrm{M}_{2} \mathrm{~L}_{1}$ registered maximum (62.14 $\left.\mathrm{kg} \quad \mathrm{ha}^{-1}\right)$ available phosphorus content followed by application of FYM @ $25 \mathrm{t} \mathrm{ha}^{-1}+$ jeevamrut (Drenching, $5 \%)\left(\mathrm{M}_{1} \mathrm{~L}_{1}\right)$ whereas minimum phosphorus content $\left(31.20 \mathrm{~kg} \mathrm{ha}^{-1}\right)$ was registered by $\mathrm{M}_{0} \mathrm{~L}_{0}$.

The increase in available phosphorus content of soil due to the incorporation of organic manures may be attributed to the direct addition of phosphorus as well as solublization of native phosphorus through release of various organic acids during the decomposition of organic matter. These findings are in line with those of Rai et al., (2014) and Singh et al., (2014). A perusal of data revealed that different organic manure treatments showed significant effects on available potassium content in soil after harvest. Significantly higher amount of available potassium in soil $\left(352.24 \mathrm{~kg} \mathrm{ha}^{-1}\right)$ was observed over control (316.48 $\left.\mathrm{kg} \mathrm{ha}^{-1}\right)$ in treatment $\mathrm{M}_{2}$, followed by application of FYM (344.25 kg ha ${ }^{-1}$ ). Drenching of soil with liquid manure also had significant effect on available potassium content. Liquid manure application registered higher available potassium (347.88 $\mathrm{kg} \mathrm{ha}^{-1}$ ) than no liquid manure application which registered available potassium content of $325.40 \mathrm{~kg} \mathrm{ha}{ }^{-1}$. Regarding the interaction effect the treatment $\mathrm{M}_{2} \mathrm{~L}_{1}$ registered maximum (362.64 $\mathrm{kg} \mathrm{ha}^{-1}$ ) available potassium content, whereas minimum potassium content $\left(298.20 \mathrm{~kg} \mathrm{ha}^{-1}\right)$ was registered in $\mathrm{M}_{0} \mathrm{~L}_{0}$.

Increase in available $\mathrm{K}$ due to organic manures application may be attributed to the direct addition of potassium to the available pool of soil. The beneficial effect of vermicompost and farmyard manure on available $\mathrm{K}$ might also be attributed to the reduction in fixation and release of $K$ due to interaction of organic matter with clay besides the direct $\mathrm{K}$ addition to the available $\mathrm{K}$ pool of soil. The present results got the support from the work of Rai et al., (2014) and Singh et al., (2014).

\section{Plant analysis}

\section{NPK uptake by plants}

The results pertaining to NPK uptake by the plant is presented in Table 2. From the table it 
was observed that the organic manures had significant influence on nutrient uptake by plants.

Among different organic manures, maximum $\mathrm{N}$ uptake by plant (145.06 $\left.\mathrm{kg} \mathrm{ha}^{-1}\right)$ was recorded in treatment $\mathrm{M}_{2}$ (vermicompost) followed by $\mathrm{M}_{1}$ viz., application of FYM (139.08 $\left.\mathrm{kg} \mathrm{ha}^{-1}\right)$. However minimum $\mathrm{N}$ uptake $\left(108.77 \mathrm{~kg} \mathrm{ha}^{-1}\right)$ was recorded in control $\left(\mathrm{M}_{0}\right)$. Application of liquid manure (Jeevamrut) recorded significantly higher $\mathrm{N}$ uptake $\left(139.24 \mathrm{~kg} \mathrm{ha}^{-1}\right)$ over the treatment $\mathrm{L}_{0}$ (no liquid manure) which registered $\mathrm{N}$ uptake value of $128.40 \mathrm{~kg} \mathrm{ha}$ respectively. Regarding interaction effect the treatment vermicompost @ $8 \mathrm{t} \mathrm{ha}^{-1}+$ jeevamrut (Drenching, 5\%) registered the highest $\mathrm{N}$ uptake value (151.93 $\left.\mathrm{kg} \mathrm{ha}^{-1}\right)$ followed by the treatment $\mathrm{M}_{1} \mathrm{~L}_{1} \quad\left[\mathrm{FYM} \quad @ 25 \mathrm{t} \mathrm{ha}^{-1}+\right.$ Jeevamrut (Drenching, 5\%)] which registered $\mathrm{N}$ uptake value of $147.75 \mathrm{~kg} \mathrm{ha}^{-1}$ respectively. Minimum nitrogen uptake value $(104.82 \mathrm{~kg}$ $\mathrm{ha}^{-1}$ ) was registered by treatment $\mathrm{M}_{0} \mathrm{~L}_{0}$ (Control).

A perusal of data revealed that different organic manure treatments showed significant effects on phosphorus uptake. Significantly higher amount of phosphorus uptake (26.49 $\left.\mathrm{kg} \mathrm{ha}^{-1}\right)$ was observed over control $(20.46 \mathrm{~kg}$ $\left.\mathrm{ha}^{-1}\right)$ in treatment $\mathrm{M}_{2}$, followed by $\mathrm{M}_{3}(24.35$ $\mathrm{kg} \mathrm{ha}^{-1}$ ). Drenching of soil with liquid manure also had significant effect on $\mathrm{P}$ uptake. Liquid manure application registered higher $\mathrm{P}$ uptake (25.34 $\mathrm{kg} \mathrm{ha}^{-1}$ ) than no liquid manure application which registered $\mathrm{P}$ uptake of $22.26 \mathrm{~kg} \mathrm{ha}^{-1}$. Regarding the interaction effect the treatment $\mathrm{M}_{2} \mathrm{~L}_{1}$ registered maximum (28.86 $\mathrm{kg} \mathrm{ha}^{-1}$ ) $\mathrm{P}$ uptake, whereas minimum phosphorus uptake (20.01 $\mathrm{kg} \mathrm{ha} \mathrm{ha}^{-1}$ was registered in $\mathrm{M}_{0} \mathrm{~L}_{0}$.

The potassium uptake by plants was influenced significantly by different organic manure treatments. Maximum amount potassium uptake $\left(114.35 \mathrm{~kg} \mathrm{ha}^{-1}\right)$ was observed in treatment $\mathrm{M}_{2}$ followed by application of FYM $\left(\mathrm{M}_{1}\right)$ and minimum amount $\left(96.77 \mathrm{~kg} \mathrm{ha}^{-1}\right)$ was observed in treatment $\mathrm{M}_{0}$.

Liquid manure application registered higher potassium uptake $\left(113.13 \mathrm{~kg} \mathrm{ha}^{-1}\right)$ than no liquid manure application which registered potassium uptake of $102.46 \mathrm{~kg} \mathrm{ha}$. Regarding the interaction effect the treatment $\mathrm{M}_{2} \mathrm{~L}_{1}$ registered maximum $\left(120.17 \mathrm{~kg} \mathrm{ha}^{-1}\right) \mathrm{K}$ which was at par with application of FYM @ $25 \mathrm{t} \mathrm{ha}^{-1}+$ jeevamrut (Drenching, 5\%), whereas minimum $\mathrm{K}$ uptake (96.42 $\mathrm{kg} \mathrm{ha}^{-1}$ ) was registered by $\mathrm{M}_{0} \mathrm{~L}_{0}$ which was at par with $\mathrm{M}_{0} \mathrm{~L}_{1}\left(99.77 \mathrm{~kg} \mathrm{ha}^{-1}\right)$.

Table.1 Physico-chemical properties of soil before planting

\begin{tabular}{|c|c|c|c|c|}
\hline Particulars & $\begin{array}{l}\text { Value } \\
\text { obtained }\end{array}$ & Range & $\begin{array}{l}\text { Soil } \\
\text { status }\end{array}$ & Method Used \\
\hline Soil pH & 7.28 & $6.8-8.7$ & Normal & $\begin{array}{l}\text { Digital pH meter (1:2 soil water } \\
\text { suspension) (Jackson, 1967) }\end{array}$ \\
\hline $\mathrm{EC}\left(\mathrm{dSm}^{-1}\right)$ & 0.42 & $\begin{array}{l}\text { Below } \\
0.8\end{array}$ & Normal & $\begin{array}{l}\text { Electrical conductivity meter (1:2 soil } \\
\text { water suspension) (Jackson, 1967) }\end{array}$ \\
\hline Organic carbon (\%) & 1.02 & $1.0-1.5$ & High & Walkley and Black, 1934 \\
\hline Available N (kg ha $\left.{ }^{-1}\right)$ & 325.00 & $272-544$ & Medium & $\begin{array}{l}\text { Alkaline potassium permanganate method } \\
\text { (Subbiah and Asija, 1956) }\end{array}$ \\
\hline Available $\mathbf{P}\left(\mathrm{kg} \mathrm{ha}^{-1}\right)$ & 45.00 & $>22.4$ & High & Olsen method (Olsen et al. 1954) \\
\hline Available K (kg ha $\left.{ }^{-1}\right)$ & 381.92 & $>337$ & High & $\begin{array}{l}\text { Normal neutral ammonium acetate } \\
\text { method (Merwin and Peech, 1951) }\end{array}$ \\
\hline
\end{tabular}


Table.2 Main and interaction effect of different organic nutrient sources on different soil properties $\mathrm{pH}, \mathrm{EC}(\mathrm{dSm}-1)$, OC (\%), Available NPK and NPK Uptake

\begin{tabular}{|c|c|c|c|c|c|c|c|c|c|}
\hline Treatments & pH & $\begin{array}{c}\mathrm{EC} \\
\left(\mathrm{dSm}^{-1}\right)\end{array}$ & $\begin{array}{l}\text { OC } \\
(\%)\end{array}$ & $\begin{array}{c}\text { Available } \\
\text { Nitrogen in soil } \\
\left(\mathrm{kg} \mathrm{ha}^{-1}\right)\end{array}$ & $\begin{array}{c}\text { Available } \\
\text { Phosphorus in } \\
\text { soil } \\
\left(\mathrm{kg} \mathrm{ha}^{-1}\right)\end{array}$ & $\begin{array}{c}\text { Available } \\
\text { Potassium in } \\
\text { soil } \\
\left(\mathrm{kg} \mathrm{ha}^{-1}\right)\end{array}$ & $\begin{array}{c}\text { Nitrogen } \\
\text { uptake } \\
\left(\mathbf{k g ~ h a}^{-1}\right)\end{array}$ & $\begin{array}{c}\text { Phosphorus } \\
\text { uptake } \\
\left(\mathbf{k g ~ h a}^{-1}\right)\end{array}$ & $\begin{array}{c}\text { Potassium } \\
\text { uptake } \\
\left(\mathbf{k g ~ h a}^{-1}\right)\end{array}$ \\
\hline$M_{0}($ No Manure $)$ & 7.28 & 0.36 & 1.13 & 251.65 & 32.60 & 316.48 & 108.77 & 20.46 & 96.77 \\
\hline$M_{1}\left(\right.$ Farm Yard Manure @ $\left.25 \mathrm{t} \mathrm{ha}^{-1}\right)$ & 7.24 & 0.27 & 1.26 & 319.34 & 49.13 & 344.25 & 139.08 & 23.94 & 112.16 \\
\hline $\mathbf{M}_{2}$ (Vermicompost @ $\left.8 \mathrm{t} \mathrm{ha}^{-1}\right)$ & 7.21 & 0.26 & 1.29 & 324.30 & 51.85 & 352.24 & 145.06 & 26.49 & 114.35 \\
\hline$M_{3}($ FYM $50 \%$ + VC $50 \%)$ & 7.26 & 0.27 & 1.23 & 311.72 & 46.79 & 337.30 & 139.27 & 24.35 & 108.56 \\
\hline$M_{4}($ FYM $75 \%+$ VC $25 \%)$ & 7.25 & 0.27 & 1.21 & 310.62 & 44.17 & 332.94 & 136.92 & 23.76 & 107.13 \\
\hline $\mathrm{CD}_{0.05}$ & NS & 0.01 & $\mathbf{0 . 0 3}$ & 3.55 & 1.69 & 3.09 & 2.59 & 0.28 & 1.82 \\
\hline $\mathbf{L}_{0}$ (No Liquid Manure) & 7.28 & 0.31 & 1.18 & 294.81 & 37.12 & 325.40 & 128.40 & 22.26 & 102.46 \\
\hline $\begin{array}{l}\mathrm{L}_{1} \text { [Liquid Manure (Jeevamrut) } \\
\text { Drenching @ } 5 \% \text { ] }\end{array}$ & 7.22 & 0.26 & 1.23 & 312.24 & 52.70 & 347.88 & 139.24 & 25.34 & 113.13 \\
\hline $\mathrm{CD}_{0.05}$ & 0.04 & 0.01 & 0.02 & 2.24 & 1.07 & 1.96 & 1.64 & 0.17 & 1.15 \\
\hline $\begin{array}{l}M_{0} \mathbf{L}_{0}[\text { No manure }+ \text { No liquid } \\
\text { manure (Control)] }\end{array}$ & 7.30 & 0.38 & 1.08 & 246.67 & 31.20 & 298.20 & 104.82 & 20.01 & 96.42 \\
\hline$M_{1} L_{0}(F Y M+$ No liquid manure $)$ & 7.27 & 0.31 & 1.22 & 307.63 & 39.50 & 337.44 & 130.40 & 21.96 & 106.10 \\
\hline $\begin{array}{l}\mathbf{M}_{2} \mathbf{L}_{0}(\text { Vermicompost + No liquid } \\
\text { manure) }\end{array}$ & 7.24 & 0.30 & 1.20 & 312.43 & 41.57 & 341.83 & 138.19 & 24.11 & 108.54 \\
\hline $\begin{array}{l}\mathrm{M}_{3} \mathrm{~L}_{0}[\mathrm{FYM}(50 \%)+\mathrm{VC}(50 \%)+\mathrm{No} \\
\text { liquid manure] }\end{array}$ & 7.29 & 0.29 & 1.21 & 302.00 & 37.35 & 328.36 & 135.29 & 22.90 & 101.45 \\
\hline $\begin{array}{l}M_{4} L_{0}[F Y M(75 \%)+V C(25 \%)+N o \\
\text { liquid manure }]\end{array}$ & 7.28 & 0.28 & 1.19 & 305.33 & 35.97 & 321.19 & 133.26 & 22.31 & 99.77 \\
\hline $\begin{array}{l}\mathbf{M}_{0} \mathbf{L}_{1}[\mathrm{No} \text { manure + Jeevamrut @ } \\
5 \%]\end{array}$ & 7.26 & 0.33 & 1.17 & 256.64 & 33.99 & 334.76 & 112.68 & 20.92 & 97.12 \\
\hline $\mathbf{M}_{1} \mathbf{L}_{1}(\mathbf{F Y M}+$ Jeevamrut @ 5\%) & 7.20 & 0.23 & 1.31 & 331.05 & 58.75 & 351.07 & 147.75 & 25.92 & 118.22 \\
\hline $\begin{array}{l}\mathbf{M}_{2} \mathbf{L}_{1} \text { (Vermicompost + Jeevamrut @ } \\
5 \%)\end{array}$ & 7.19 & 0.22 & 1.38 & 336.16 & 62.14 & 362.64 & 151.93 & 28.86 & 120.17 \\
\hline $\begin{array}{l}\mathrm{M}_{3} \mathrm{~L}_{1}[\mathrm{FYM}(50 \%)+\mathrm{VC}(50 \%)+ \\
\text { Jeevamrut @ 5\%] }\end{array}$ & 7.22 & 0.24 & 1.25 & 321.44 & 56.23 & 346.23 & 143.25 & 25.81 & 115.67 \\
\hline $\begin{array}{l}\mathrm{M}_{4} \mathrm{~L}_{1}[\mathrm{FYM}(25 \%)+\mathrm{VC}(\mathbf{7 5 \%})+ \\
\text { Jeevamrut@5\%] }\end{array}$ & 7.21 & 0.26 & 1.23 & 315.90 & 52.37 & 334.69 & 140.58 & 25.21 & 114.50 \\
\hline Overall Mean & 7.25 & 0.29 & 1.27 & 303.53 & 44.91 & 336.64 & 133.82 & 23.8 & 107.80 \\
\hline $\mathrm{CD}_{0.05}$ & NS & 0.02 & 0.04 & 5.03 & 2.39 & 4.37 & 3.66 & 0.40 & 2.57 \\
\hline
\end{tabular}


Table.3 Effect of different organic nutrient sources on economics of onion production

\begin{tabular}{|c|c|c|c|c|c|c|}
\hline \multicolumn{7}{|c|}{ Table 3: Effect of different organic nutrient sources on economics of onion production } \\
\hline Sr. No. & Treatments & $\begin{array}{c}\text { Yield } \\
\left(\mathbf{q} \text { ha }^{-1}\right)\end{array}$ & $\begin{array}{l}\text { Gross Income } \\
\left(\text { Rs. ha }{ }^{-1}\right)\end{array}$ & $\begin{array}{c}\text { Cost of Cultivation } \\
\left(\text { Rs. } \text { ha }^{-1}\right)\end{array}$ & $\begin{array}{l}\text { Net Return } \\
\left(\text { Rs. ha }{ }^{-1}\right)\end{array}$ & B:C Ratio \\
\hline 1 & $\mathrm{M}_{0} \mathrm{~L}_{0}$ & 261.78 & 523556.89 & 98250 & 425306.89 & 4.33 \\
\hline 2 & $\mathrm{M}_{1} \mathrm{~L}_{0}$ & 311.98 & 623955.56 & 144550 & 479405.56 & 3.32 \\
\hline 3 & $\mathrm{M}_{2} \mathrm{~L}_{0}$ & 325.65 & 651296.30 & 147350 & 503946.30 & 3.42 \\
\hline 4 & $\mathrm{M}_{3} \mathrm{~L}_{0}$ & 301.13 & 602266.67 & 145950 & 456316.67 & 3.13 \\
\hline 5 & $\mathrm{M}_{4} \mathrm{~L}_{0}$ & 296.00 & 592000.00 & 145250 & 446750.00 & 3.08 \\
\hline 6 & $\mathrm{M}_{0} \mathrm{~L}_{1}$ & 282.72 & 565440.00 & 100975 & 464465.00 & 4.60 \\
\hline 7 & $\mathrm{M}_{1} \mathrm{~L}_{1}$ & 383.73 & 767466.67 & 146675 & 620791.67 & 4.23 \\
\hline 8 & $\mathrm{M}_{2} \mathrm{~L}_{1}$ & 429.19 & 858370.37 & 149475 & 708895.37 & 4.74 \\
\hline 9 & $\mathrm{M}_{3} \mathrm{~L}_{1}$ & 374.77 & 749540.74 & 145875 & 603665.74 & 4.14 \\
\hline 10 & $\mathrm{M}_{4} \mathrm{~L}_{1}$ & 356.17 & 712340.74 & 147375 & 564965.74 & 3.83 \\
\hline
\end{tabular}


The higher nutrient (NPK) uptake with application of organic manure could be due to addition of plant nutrients directly through organic manures and indirectly through solublization of unavailable native nutrients and chelation of complex intermediate organic molecules produced during decomposition of added manures. Application of jeevamrut increased the number of microorganisms in the soil and decomposition of organic manures which resulted into availability of more nutrients to the plants. Other possible reason might be improved physical and chemical properties of the soil leading to better root growth which helps into better nutrient uptake. Similar results have also been reported by Ngullie et al., (2011) and Thangasamy et al., (2015).

\section{Economics of treatments}

It was observed from the data given in Table 3 that among different treatments net returns were highest (Rs. 7,08,895.37 ha ${ }^{-1}$ ) in $\mathrm{M}_{2} \mathrm{~L}_{1}$ [Vermicompost + Jeevamrut (Drenching 5 \%)] followed by $\mathrm{M}_{1} \mathrm{~L}_{1}$ (Rs. 6,20,791.67 ha' ${ }^{-1}$ ), whereas lowest net returns (Rs. 4,25,306.89 $\left.\mathrm{ha}^{-1}\right)$ were calculated in Control $\left(\mathrm{M}_{0} \mathrm{~L}_{0}\right)$. Maximum B:C ratio (4.74) was obtained by $\mathrm{M}_{2} \mathrm{~L}_{1}$ [Vermicompost @ $8 \mathrm{t} \mathrm{ha}^{-1}+$ Jeevamrut (Drenching $5 \%$ )] followed by application of $\mathrm{M}_{0} \mathrm{~L}_{1}$ (4.60) whereas minimum $\mathrm{B}: \mathrm{C}$ ratio (3.08) was recorded in $\mathrm{M}_{4} \mathrm{~L}_{0}$ [No manure + Jeevamrut (Drenching, 5\%)].

Higher net return under $\mathrm{M}_{2} \mathrm{~L}_{1}$ [Vermicompost + Jeevamrut Drenching (5\%)] treatment could be ascribed to the higher bulb yield of onion obtained under this treatment. Good vegetative growth and better soil conditions resulted into higher yield. More increase in economic yield as compared to increase in expenditure resulted in higher total gross income, net returns and $\mathrm{B}: \mathrm{C}$ ratio. It was also observed that there were no losses due to insect pests and diseases in the present investigation. Further, cost of cultivation can be reduced by producing the vermicompost on farm by the farmers themselves. Similar results have been reported by Channagouda et al., (2015) and Meena et al., (2016).

\section{References}

Channagouda RF, Babalad HB and Patil RK. 2015a. Performance of cotton under organic production system. Research on Crops 16:264-270.

Jackson MI. 1973. Soil Chemical Analysis. Prentice Hall of India Pvt. Ltd. New Delhi, India, pp.219-221.

Jackson ML. 1967. Soil Chemical Analysis. Prentice Hall of India. New Delhi.pp.111-126

Meena SL, Bairwa HL, Mahawer LN, Meena MS, Chittora A and Meena S. 2016. Effect of integrated nutrient management on growth, yield and quality of onion cv. N-53. Research on Crops 17:550-554.

Merwin HD and Peech M. 1951. Exchange ability of soil potassium in the sand, silt and clay fraction as influenced by the nature and complementary exchangeable cations. Soil Science American Proceedings 15:125-128.

Ngullie E, Singh VB, Singh AK and Singh H. 2011. Fertilizing for sustainable onion production system. Vegetable Science 95:32-34.

Olsen SR, Cole CV, Watenable DS and Dean LA.1954. Estimation of available phosphorus in soils by extraction with sodium bicarbonate. USDS Circular, $939 \mathrm{p}$.

Panse VG and Sukhatme PV. 2000. Statistical methods for agricultural workers. Indian Council of Agricultural Research, New Delhi. pp. 157-165.

Rai S, Rani P, Kumar M, Rai AK and Shahi SK. 2014. Effect of integrated use of vermicompost, FYM, PSB and 
Azotobacter on physico-chemical properties of soil under onion crop. Environment and Ecology 32:17971803.

Singh SN, Rai JP, Singh SR, Goyal SK and Singh SP. 2014. Effect of integrated use of organic manures and fertilizers on yield, nutrient uptake and soil fertility in onion on red soils of Vindhyan region. Vegetable Science 41: 150-154.

Subbiah BV and Asija GL. 1956. A rapid procedure for the estimation of the available nitrogen in soils. Current
Science 25:259-260.

Thangasamy A and Lawande KE. 2015. Integrated nutrient management for sustainable onion production. Indian Journal of Horticulture 72:347-352.

Vavilov NI. 1951. Origin, variation, immunity and breeding of cultivated plants. Journal of Chronical Botany 13:1-364.

Walkley $A$ and Black TA.1934. An estimation of soil organic matter and proposed modification of the chromic acid titration method. Soil Science 37:29-38.

\section{How to cite this article:}

Ravina Kumari, Kuldeep Singh Thakur and Noel Lalhruaitluangi. 2019. Effect of Different Organic Nutrient Sources on Soil Properties in Onion (Allium cepa L.). Int.J.Curr.Microbiol.App.Sci. 8(04): 1783-1792. doi: https://doi.org/10.20546/ijcmas.2019.804.207 